Journal of Development and Social Change, Vol. 2, No. 1, April 2019

p-ISSN 2614-5766, https://jurnal.uns.ac.id/jodasc

\title{
ETOS KERJA MASYARAKAT MISKIN PEDESAAN (STUDI FENOMENOLOGI PADA MASYARAKAT DESA SEWUREJO KECAMATAN MOJOGEDANG KABUPATEN KARANGANYAR)
}

\author{
Muchlisa Salma Nur Hartanti ${ }^{1}$, Drajat Tri Kartono ${ }^{2}$ \\ Program Studi Sosiologi Fakultas Ilmu Sosial dan Politik \\ Universitas Sebelas Maret Surakarta Indonesia \\ Email1': lisalmaar@gmail.com, Email²: drajat.uns@gmail.com
}

\begin{abstract}
This research examines the poor residences living in Sewurejo Village that are included in IDT (Inpres Desa Tertinggal). The work ethic is one important factor for the framework of poor residences in Sewurejo Village. In fulfilling their daily needs, those residences need to work. The working habit of Sewurejo Village poor residents illustrates their work ethic in general. It can be used as a work ethic parameter of the poor residences and how the religion affects it. This research aims to determine the work ethic of poor residence and the effect of religion to work ethic. This research uses qualitativephenomenological method and Protestant's Ethic theory and Max Webber's Capitalism Spirit. The samples are taken using purposive sampling.

The results shows that Sewurejo Village residents are industrious and most of them work as construction workers, farm workers, merchants, industrial workers, and scavengers. For most of the residents of Sewurejo Village, the religion can affect the work ethic and vice versa, vice versa can also affect the work ethic. It can be seen in some indicators such as capital accumulation, religious manifestations, networks, and using their free time to worship so that they can go to heaven smoothly.
\end{abstract}

Keywords: Work Ethics, Phenomenology, Poor People

Abstrak: Penelitian ini hendak dilakukan pada masyarakat miskin yang berada di Desa Sewurejo yang termasuk dalam IDT (Inpres Desa Tertinggal). Etos kerja merupakan factor penting bagi kerangka kerja masyarakat miskin Desa Sewurejo. Untuk memenuhi kebutuhan sehari-hari masyarakat miskin harus bekerja menjadi hal utama yang dapat dilakukan. Kebiasaan melakukan pekerjaan yang dilakukan masyarakat miskin Desa Sewurejo membentuk sebuah gambaran etos kerja masyarakat miskin Desa Sewurejo secara umum. Kebiasaan tersebut dapat menjadi ukuran bagaimana etos kerja masyarakat miskin dan bagaimana agama mempengaruhi etos kerja masyarakat miskin. Hal inilah yang melatar belakangi penelitian ini. Penelian ini bertujuan untuk mengetahui gambaran etos kerja masyarakat miskin dan pengaruh agama dalam etos kerja. Penelitian ini menggunakan metode penelitian fenomenologi-kualitatif dan menggunakan teori Etika Protestan dan Spirit Kapitalisme Max Weber. Teknik pengambilan sampel yang digunakan yaitu purposive sampling. Hasil penelitian ini menunjukan, etos kerja masyarakat miskin Desa Sewurejo adalah rajin dari mayoritas masyarakat dalam menjalani profesi yang mereka jalani seperti: buruh bangunan, buruh tani, pedagang, buruh industri dan buruh rosok. Agama berpengaruh terhadap etos kerja dan bisa terjadi sebaliknya yaitu etos kerja bisa mempengaruhi agama terlihat dalam beberapa indikator yang bersangkutan meliputi penumpukan modal, manifestasi agama, jaringan, dan pemanfaatan waktu luang dengan mengharapkan sebuah pahala dari ibadah yang dilakukannya demi menuntunnya ke surga.

Kata Kunci: Etos Kerja, Fenomenologi, Masyarakat Miskin 


\section{PENDAHULUAN}

Permasalahan kemiskinan bukan hanya merupakan masalah ekonomi semata, akan tetapi juga merupakan masalah sosial dan kemanusiaan. Oleh karena itu, implikasi permasalahan kemiskinan dapat mempengaruhi berbagai aspek kehidupan manusia secara keseluruhan, yang pada akhirnya akan menentukan kelangsungan pembangunan kualitas manusia itu sendiri yang meliputi pendidikan, kesehatan, ketenagakerjaan, infrastruktur dasar dan ketahanan pangan. Dalam kaitan proses perkembangan dinamika kehidupan masyarakat, maka masalah kemiskinan dipandang sebagai masalah yang sangat dinamis, sehingga membutuhkan peran institusi, program serta metode pendekatan yang mempu menjawab permasalahan kemiskinan, yang bertumpu pada beberapa nilai dasar filosofi yaitu rasa, karsa dan cipta sebagai kata kunci dalam pelaksanaan pemberdayaan sosial (Redmod \& Johnson, 1992; Sumodiningrat, 2008).

Persoalan kemiskinan juga diakibatkan dari kurang kesadaran pemerintah dan masyarakat dalam memaknai pentingnya pendidikan, sesunguhnya pendidikan itu merupakan pusat dalam pembangunan manusia yang cerdas dan berkualitas, dan sangat mendorong pertumbuhan ekonomi, politik, sosial, dan budaya demi kemajuan daerah tersebut. Berdasarkan data kemiskinan yang dipublikasi BPS, perkembangan persentase penduduk miskin Kabupaten Karanganyar pada tahun 2013 hingga tahun 2018 mengalami penurunan, yaitu pada tahun sebesar 13,58\% menurun pada tahun 2018 menjadi 10,01\%, meskipun pada tahun 2016 pernah naik menjadi menjadi sebesar 12,49\% dibandingkan tahun 2015 sebesar 12,46\%. Pemerintah Kabupaten Karanganyar telah berupaya mengurangi pengentasan kemiskinan melalui berbagai program pembangunan. Namun pencapaian persentase penduduk miskin masih tergolong tinggi masalah kemiskinan di Kabupaten Karanganyar masih kompleks. Wilayah Kabupaten Karanganyar merupakan daerah yang cukup subur. Mayoritas penduduknya bermata pencaharian di bidang ekonomi lemah, sehingga kehidupan ekonomi kurang berkembang secara signifikan.

Berdasarkan data kemiskinan Per-Kecamatan di Kabupaten Karanganyar yang di publikasikan Basis Data Terpadu TNP2K, Kecamatan Mojogedang merupakan daerah termiskin karena sebesar 29.299 ribu jiwa penduduk Kecamatan Mojogedang masih mengalami kemiskinan. Permasalahan kemiskinan beragam bukan hanya soal ekonomi, tetapi sosial, budaya, pendidikan dan sebagainya. Untuk memenuhi kebutuhan hidup sehari-hari tentu diperlukan aktiftas-aktivitas ekonomi yang dapat menghasilkan uang untuk memenuhi kebutuhan ekonomi, pendidikan dan lain-lain. Aktivitas ekonomi seperti mencari rongsok, bekerja menjadi buruh di kebun karet, bekerja menjadi buruh di pabrik dan lain sebagainya tentu diperlukan kerja keras sebagai upaya untuk memperoleh dan memenuhi kebutuhan hidup. Semangat atau etos kerja inilah yang kemudian mengantarkan masyarakat di Desa Sewurejo untuk selalu terpacu untuk memenuhi kebutuhan hidup sehari-harinya.

Berkerja adalah fitrah dan sekaligus merupakan salah satu identitas manusia, sehingga berkerja yang berdasarkan pada prinsip-prinsip iman tauhid, bukan saja menunjukan fitrah seorang muslim, tetapi sekaligus meninggikan martabat dirinya (Toto Tasmara, 1995). Dalam usaha untuk memenuhi kebutuhan hidup, manusia diharapkan untuk bekerja keras dan tekun guna memperoleh hasil yang maksimal dan memuaskan. Dengan demikian maka seseorang dituntut untuk tidak cepat merasa puas dengan hasil yang telah dicapai, karena jika demikian maka akan menurunkan semangat kerja keras orang tersebut, yang tentu akan membawa dampak pada hasil yang akan dicapai.

Membahas tentang etos kerja masyarakat guna meningkatkan tingginya etos kerja sebagai upaya untuk meningkatkan mutu produk dan kesejahteraan masyarakat, salah satunya dapat dilakukan dengan mengupayakan peningkatan pemahaman terhadap ajaran agama yang 
dianut. Hal ini berdasarkan pada hasil dari pengamatan Weber, bahwa adanya suatu kebudayaan yang menganggap bahwa kerja keras merupakan suatu keharusan setiap manusia untuk mencapai kesejahteraan. Pandangan dan pengamatan Weber tersebut oleh beberapa ahli sosial dijadikan sebagai suatu pandangan dalam menganalisa pembangunan suatu negara dan bangsa. (Sadly, Effendi. 2017. Etos Kerja Pada Masyarakat Nelayan di Desa Bagan Kuala Kecamatan Tanjung Beringin Kabupaten Serdang Bedagai. Doktor Ekonomi Syariah. Universitasi Islam Negeri Sumatera Utara.)

Dengan demikian jika akan melihat apakah pembangunan itu berhasil atau tidak, dapat dilihat dari ada tidaknya etos kerja dalam masyarakat. Dengan kata lain etos kerja dalam masyarakat untuk pembangunan masyarakat atau untuk meningkatkan produktivitas kerja (Mubyarto, 1991). Masyarakat pedesaan khususnya masyarakat di Desa Sewurejo Kecamatan Mojogedang Kabupaten Karanganyar biasanya melakukan aktivitas-aktivitas yang berhubungan dengan usaha pertanian sesuai dengan kondisi lokasi, fisik dan sumber daya setempat guna memenuhi kebutuhan hidup sehari-hari yang dekat Sebagian besar masyarakat Desa Sewurejo berprofesi sebagai petani dengan komoditas unggulannya adalah padi, penghasil padi terbesar terdapat di Dusun Gragalan dan Jubleg. Sebesar 963 orang berprofesi sebagai petani dan 342 orang sebagai buruh tani karena memang area pertanian baik sawah irigasi maupun lahan kering masih mendominasi penggunaan lahan di Desa Sewurejo.

Mayoritas masyarakat Desa Sewurejo memeluk agama islam yaitu sebesar 5.340 jiwa penduduk mempercayai islam sebagai agama yang diyakini kegiataan keagamaan yang biasanya dilakukan seperti pengajian, rowatiban, sholawatan bahkan yasinan. Kemudian warga yang menganut agama protestan sebanyak 36 jiwa dan yang beragama hindu sejumlah 4 orang. Peran Agama dalam kehidupan sosial terkait erat dengan perkembangan pola pikir manusia, sehingga agama juga memainkan peran yang sangat besar dalam proses perubahan sosial dimasyarakat. Dalam bukunya "The Protestant Ethic and The Spirit of Capitalism", Weber dalam buku tersebut menjelaskan mengenai bagaimana doktrin agama memegang peran kunci dalam proses perkembangan kapitalisme di kawasan Eropa. Weber (1992) menyebutnya sebagai etika protestant. Agama merupakan sumber semangat bagi manusia karena didalamnya ada banyak doktrin atau ajaran yang turut mempengaruhi cara berpikir para pengikutnya. (Martono Nanang, Sosiologi Perubahan Sosial perspektif Klasik, Modern, Posmodern, dan Poskolonial (Jakarta: PT Rajagrafindo Persada 2014), hal. 314). Menarik untuk diteliti tentang etos kerja ini karena, untuk mengetahui bagaimana masyarakat memandang tentang etos kerja serta faktor apa yang mempengaruhi etos kerja masyarakat atau individu. Perbedaan ini dapat dilihat pada anggota masyarakat dusun yang menjadi lokasi penelitian.

\section{METODE}

Penelitian ini dilakukan di Desa Sewurejo, Kecamatan Mojogedang, Kabupaten Karanganyar, karena termasuk Desa yang paling tertinggi jumlah penduduk miskin di Kecamatan Mojogedang. Menurut rekap data dari Adress PBDT 2015, jumlah penduduk miskin sebanyak 3,578 (jiwa) dan saat ini kondisi di Desa Sewurejo pembangunan fisik cukup maju tetapi masih perlu adanya pengembangan sumber daya manusia dan tingkat pendidikan masyarakat masih rendah oleh sebab itu, Desa Sewurejo tergolong desa tertinggal yang masuk dalam IDT (Indeks Desa Tertinggal) di Kabupaten Karanganyar. Penelitian ini merupakan penelitian kualitatif dengan pendekatan fenomenologi. Teknik pengambilan sampel yang digunakan adalah purposive sampling dengan informan terdiri dari beberapa masyarakat yang bekerja di Desa Sewurejo. Data dikumpulkan melalui wawancara 
mendalam dengan seluruh informan dan mengobservasi karakteristik informan, serta mengkaji dokumen terkait etos kerja masyarakat miskin. Untuk menguji validitas data dilakukan triangulasi sumber membandingkan jawaban informan lain dalam mengcroscek data yang diperoleh langsung data sehingga antara data yang satu terkontrol oleh data yang lain. Teknik analisis daya menggunakan model analisis interaktif dari Miles dan Hubermas dengan teori Etika Protestan dan Semangat Kapitalisme, yang terdiri dari tiga skema secara bersamaan, yaitu reduksi data, penyajian data dan penarikan kesimpulan.

\section{PEMBAHASAN}

\section{Etos Kerja Masyarakat Miskin Desa Sewurejo, Kecamatan Mojogedang, Kabupaten Karanganyar}

Etos Kerja Menurut Max Weber (Mabyarto, Etos...., h.3) adalah sikap dari masyarakat terhadap makna kerja sebagai pendorong keberhasilan usaha dan pembangunan. Etos kerja merupakan fenomena sosiologi yang eksistensinya terbentuk oleh hubungan produktif yang timbul sebagai akibat dari struktur ekonomi yang ada dalam masyarakat. Etos dalam penelitian ini dibagi menjadi dua yaitu etos kerja rajin dan etos kerja malas. Etos kerja rajin adalah segala sesuatu yang membuat seseorang terdorong untuk bekerja dengan giat, sedangkan etos kerja malas adalah segala sesuatu yang menjadi penghambat keberhasilan seseorang. Etos kerja dilihat dari beberapa indikator yaitu penumpukan modal, manifestasi agama, jaringan, pemanfaatan waktu luang. Penumpukan modal merupakan atau investasi merupakan pilar penting dalam pertumbuhan ekonomi suatu Negara yang hendak tumbuh berkelanjutan memerlukan modal terus-menerus. (Dhaniswara K. Haryono, Op.Cit, hlm. 68). Manifestasi agama adalah perwujudan sebagai suatu pernyataan perasaan atau pendapat masyarakat tentang agama. Jaringan disini adalah berkembangnya kelompok-kelompok agama yang dilakukan oleh masyarakat diisi dengan kegiatan keagamaan seperti halnya dalam islam misalnya pengajian. Pemanfaatan waktu luang dijelaskan apa saja yang dilakukan oleh penduduk ketika beristirahat dari waktu luangnya seperti halnya makan siang, ataupun melakukan kewajibannya seperti sholat.

\section{- Etos Kerja Rajin Masyarakat Miskin Desa Sewurejo}

a) Penumpukan Modal

Beberapa aset yang dimiliki oleh sebagian besar penduduk Desa Sewurejo dari berbagai macam pekerjaan yaitu bermacam-macam jenis mulai dari hewan peliharaan seperti kambing ataupun sapi seperti pada umumnya, kemudian ada yang menabung digunakan untuk keperluan hari raya lebaran ataupun untuk beribadah umroh di tanah suci, lalu aset yang tidak langsung dirasakan manfaatnya namun bersifat jangka panjang yaitu dengan infaq dan shodaqoh yang mendapatkan imbalan di surga nanti dalam kehidupan selanjutnya. Dan yang terakhir berupa sawah yang dimiliki oleh petani sebagai penunjang pekerjaannya

b) Manifestasi Agama

Berbicara tentang agama memerlukan suatu sikap yang ekstra hati-hati. Sebab agama merupakan persoalan sosial, tetapi penghayatannya sangat bersifat individual. Apa yang dipahami dan apa yang dihayati sebagai agama oleh seseorang sangat tergantung pada keseluruhan latar belakang dan kepribadiannya. Setiap manusia mempunyai pandangan yang berbeda-beda tentang agama, secara keseluruhan informan memeluk agama Islam dan hampir 90\% populasi penduduk Desa Sewurejo pun beragama Islam. Mereka memahami bahwa agama adalah sebuah kepercayaan dan keyakinan yang menuntun mereka untuk kehidupan selanjutnya yang di dalam Islam masih ada kehidupan selain di dunia ini yaitu di akhirat. Agama adalah sebuah pondasi bagi manusia untuk tingkah laku dalam kehidupan sehari-hari 
yang bisa dipraktekkan hal-hal yang baik. Bagi agama islam adalah menjalankan ibadah yaitu dengan sholat lima waktu, puasa, zakat dan haji bila yang mampu.

c) Jaringan

Mayoritas masyarakat mengikuti pengajian selalu teratur dilaksanakan pada Sabtu malam minggu yang bertempat di masjid yang terdekat dengan rumah penduduk dimulainya pengajian tersebut sehabis sholat isya' atau sekitar jam 8 malam hingga selesai. Materi yang dibawakan setiap bulannya pun berbeda-beda, tak lupa manfaat yang dirasakan yaitu menambah pengetahuan di bidang agama agar hati tidak menjadi kosong dan hampa. Selain pengajian, juga ada yasinan keliling, rowatiban dan sholawatan.

d) Pemanfaatan Waktu Luang

Menyempatkan untuk melakukan sembahyang di sela-sela kesibukan bekerja ketika sudah memasuki waktu untuk sholat adalah yang dilakukan oleh kedua informan diatas. Setidaknya menyempatkan waktu untuk melakukan sembahyang selama kurang lebih 5 smpai 10 menit dengan membagi waktu dengan baik. Setiap pekerjaan harus dilakukan dengan kerja keras agar hasilnya menjadi maksimal, tak lupa sebagai umat yang beragama islam bahwasanya harus menunaikan sholat 5 (lima) waktu sebagai kewajibannya yang terdiri dari sholat subuh, sholat dhuhur, sholat ashar, sholat maghrib dan sholat isya'. Tiap pekerjaan pasti mempunyai waktu istirahat yang digunakan untuk makan siang dan sisanya sebagai umat yang beragama digunakan untuk sembahyang menghadap Sang Khaliq

- Etos Kerja Malas Masyarakat Miskin Desa Sewurejo

a) Penumpukan Modal

Minoritas penduduk merasakan tidak memiliki aset karena penghasilan sehari-hari yang sudah dilakukan dengan bekerja hanya cukup untuk memenuhi kebutuhan hidupnya saja dan belum cukup untuk membeli aset bahkan untuk menabung. Bahkan terkadang tidak mempunyai sisa dari penghasilannya karena untuk kebutuhan tambahan seperti kebutuhan sosial yang berada dalam masyarakat pedesaan adalah menyumbang kepada tetangga yang sedang memiliki hajatan.

b) Manifestasi Agama

Pemahaman masyarakat tentang agama bisa jadi berbeda-beda sesuai dengan apa yang mereka ketahui dan pahami. Ada yang menyebutkan bahwa agama merupakan sebuah perintah dari sang Maha Kuasa untuk menjalankan ibadah, selain itu ada yang menyebutkan agama baik jika digunakan dalam memperoleh rezeki, mendidik anak dan lain sebagainya. Akan tetapi, ada juga yang tidak memahami agama secara lebih mendalam karena belum bisa dan belum memahami lebih lanjut.

c) Jaringan

Sebagian kecil masyarakat mengaku tidak mengikuti pengajian karena berbagai macam hal, buruh industri mereka tidak mengikuti pengajian dikarenakan masalah waktu di pekerjaannya masing-masing buruh industri tidak bisa mengikuti karena terkadang mendapatkan shift siang yang waktu bekerjanya dari siang hingga malam hari begitu pula pedagang juga setelah ia selesai bekerja sudah malam dan tidak memungkinkan untuk menghadirinya. Akan tetapi berbeda dengan buruh bangunan dan buruh rosok mengaku bahwasanya mereka mengetahui akan adanya pengajian tersebut tapi mereka memilih untuk tidak menghadirinya.

d) Pemanfaatan Waktu Luang

Terkadang telah memasuki waktu untuk sholat akan tetapi, masih melakukan pekerjaan yang membuatnya untuk menunda akan kewajibannya tersebut. Lalu ketika sudah selesai melakukan pekerjaan tersebut telah berganti memasuki waktu untuk sholat yang lain 
hal yang dilakukan adalah dengan menjamak sholat tersebut tetapi kadang-kadang justru malah lupa dan tidak melakukan kewajibannya tersebut. Tetapi ada juga terkadang lalai dalam melakukan kewajibannya tersebut beralasan merasa lelah dan tidak sempat dan sebagainya.

\section{Pengaruh Agama Terhadap Etos Kerja Masyarakat Miskin}

Berdasarkan pandangan Geertz (C. Geertz dalam Nur Syam, Islam Pesisir, (Yogyakarta: LKiS. 2005), hlm. 01) yang menyatakan bahwa agama merupakan bagian yang tidak terpisahkan dari sistem kebudayaan manusia yang telah tertanam dalam keseharian masyarakat. Tindakan dan perilaku masyarakat merupakan bagian dari interpretasi atas agama dan dijadikannya sebagai sebuah pola atas kehidupan sosial masyarakat secara umum. Tindakan yang dikategorikan sebagai pola atas agama ini merupakan tindakan yang hidup dalam masyarakat yang tercermin dalam kehidupan sehari-hari. Sehingga aktivitas seseorang dalam masyarakat tidak lepas dari keterlibatan dan persinggungannya dengan agama. Tak terkecuali masyarakat di Desa Sewurejo, Kecamatan Mojogedang, Kabupaten Karanganyar yang mayoritas beragama Islam.

\section{a) Penumpukan Modal}

Aset yang dimiliki oleh penduduk desa sewurejo berbagai jenis dan bermacammacam pula kegunaannya. Ada yang menggunakan untuk agama seperti contohnya hewan peliharaan berupa kambing yang nantinya bisa bermanfaat untuk hewan qurban, lalu tabungan yang semata-mata menabung setiap bulannya demi bisa beribadah umroh ke tanah suci dan yang terakhir yaitu dengan berinfaq dan bershodaqoh yang ingin masuk ke dalam surga dalam kehidupan di akhirat. Serta ada pula yang tidak misalnya hewan peliharaan itu hanya untuk tabungan atau jika ada kebutuhan mendadak, tabungan pada hari raya yang berguna untuk memenuhi kebutuhan hari raya yang banyak dan realita di masyarakat semua bahan meningkat dan yang terakhir berupa sawah yang memiliki peranan juga untuk pekerjaannya agar bisa menghidupi keluarganya.

\section{b) Manifestasi Agama}

Agama ternyata mempunyai pengaruh yang besar kepada masyarakat, salah satunya ketika sebelum memulai aktifitasnya bekerja ada yang mengawalinya dengan berdoa agar diberikan kelancaran dan keselamatan serta agar tidak ada gangguan. Sebagian besar masyarakat menggunakan agama sebagai kontrol sosial untuk melakukan setiap tingkah laku dalam aktivitas yang dijalankannya dan agar tidak terpegaruh kepada hal-hal yang bersifat negatif. Mengajarkan lebih ikhlas dan sabar jika ada kondisi-kondisi yang kurang berpihak kepadanya serta akibat dari kesalahannya sendiri juga menerima segala konsekuensinya. Dan lebih mengedepankan kewajibannya untuk menyembah Sang Kuasa dibandingkan bekerja karena bekerja bisa dilakukan setelahnya atau lain waktu.

c) Jaringan

Sebagian masyarakat merasa memiliki sebuah kewajiban untuk menghadiri pengajian jika akan diadakan sebuah pengajian yang secara rutin digelar setiap bulannya. Mereka merasa bahwa belum mengetahui agama secara lebih mendalam dan manfaat yang dirasakan setelah mengikuti pengajian adalah dari berawal tidak tahu menahu soal agama menjadi tahu, menambah informasi ataupun wawasan tentang agama dan yang paling utama menjadikan pribadi yang lebih baik lagi dari yang sebelumnya. Sebagian kecil penduduk yang tidak menghadiri pengajian karena berbagai alasan, pertama ketika pulang kerumah setelah selesai dari pekerjaannya masih dibebankan oleh pekerjaan rumah yang menuntutnya sebagai ibu rumah tangga sehingga tidak ada waktu untuk keluar rumah apalagi untuk berkumpul dengan tetangga, lalu tidak mengetahui agama secara mendalam hanya sebatas tahu saja yang 
menyebabkan tidak mengikuti pengajian itu dan yang terakhir karena masalah waktu akibat pekerjaannya yang hingga malam dan akibatnya tidak bisa menghadiri pengajian tersebut.

d) Pemanfaatan Waktu Luang

Di sela-sela istirahat dalam melakukan pekerjaannya, sebagian besar masih bisa untuk menyempatkan waktu untuk menunaikan kewajibannya sebagai umat islam dengan sholat serta digunakan untuk istirahat sebentar dan makan siang. Jika tidak berada dalam waktu untuk sholat tetap diberikan keringanan untuk sholat dan dilakukan secara bergantian. Serta sesibuk apapun pekerjaannya tetap mengusahakan untuk menjalankan kewajibannya tersebut walaupun terkadang terlambat waktunya. Namun ada beberapa masyarakat yang menggunakan waktu istirahatnya ketika bekerja untuk beristirahat karena merasa kelelahan akibat bekerja kemudian juga digunakan untuk makan siang dan bahkan tidak melakukan kewajiban dari agama yang diyakini karena beralasan tidak sempat.

\section{KESIMPULAN}

Etos kerja masyarakat miskin Desa Sewurejo memiliki etos kerja rajin dilihat dari beberapa indikator seperti penumpukan modal sebagian besar telah memiliki aset seperti hewan peliharaan, tabungan, infaq maupun shodaqoh serta sawah, manifestasi agama mayoritas penduduk memahami agama sebagai kepercayaan dalam beribadah dengan mematuhi segala perintah serta menjauhi segala larangannya dan juga untuk pedoman dalam mengatur tingkah laku agar tidak terpengaruh dalam hal-hal yang negatif, di dalam jaringan sebagian besar masyarakat mengikuti pengajian rutin yang selalu dilaksanakan setiap bulannya di masjid dan pemanfaatan waktu luang mayoritas menggunakan waktu luang untuk menunaikan kewajiban mereka sebagai umat muslim yaitu dengan sholat lima waktu. Meskipun ada beberapa yang tidak memiliki etos kerja rajin. Berhubungan dengan pengaruh agama terhadap etos kerja masyarakat miskin Desa Sewurejo dan bisa terjadi sebaliknya yaitu etos kerja bisa mempengaruhi agama. Yang melatar belakangi pengaruh agama terhadap etos kerja mereka adalah dari diri sendiri masing-masing karena tidak semua orang mempunyai tingkat pemahaman terhadap agama yang sama meskipun dalam satu lingkup pengajian yang sama.

\section{DAFTAR PUSTAKA}

Haryono, Dhaniswara K. 2007. Hukum Penanaman Modal. Jakarta, Raja Grafindo Persada. Martono Nanang. 2014. Sosiologi Perubahan Sosial perspektif Klasik, Modern, Posmodern, dan Poskolonial Jakarta: PT Rajagrafindo Persada, hal. 314

Laporan Akhir Strategi Penanggulangan Kemiskinan Daerah Kabupaten Karanganyar Tahun 2018-2023 dari Badan Perencanaan Penelitian Dan Pengembangan Daerah (BAPERLITBANGDA) Kabupaten Karanganyar.

Mubyarto, dkk. 1991. Etos Kerja dan Kohesi Sosial. Yogyakarta: Aditya Media

Nursyam. 2005. Islam Pesisir. Yogyakarta: LkiS

Sadly, Effendi. 2017. Etos Kerja Pada Masyarakat Nelayan di Desa Bagan Kuala Kecamatan Tanjung Beringin Kabupaten Serdang Bedagai. Doktor Ekonomi Syariah. Universitasi Islam Negeri Sumatera Utara 